\section{Integrated isotopic studies of auriferous pyrite: implication for the genesis of the giant Jinchangyu gold deposit, North China Craton}

\author{
YANG BAI ${ }^{1,2,3,4}$, LING LI ZHOU ${ }^{5}$ AND LIAN CHANG \\ $\mathrm{ZHANG}^{1,2,3}$
}

${ }^{1}$ Key Laboratory of Mineral Resources, Institute of Geology and Geophysics, Chinese Academy of Sciences, Beijing

${ }^{2}$ Innovation Academy for Earth Science, Chinese Academy of Sciences, Beijing

${ }^{3}$ College of Earth and Planetary Sciences, University of Chinese Academy of Sciences, Beijing

${ }^{4}$ Department of Earth Sciences, Durham University, Durham

5 iCRAG, School of Earth Sciences, University College Dublin, Belfield, Dublin 4

Presenting Author: yangb7924@gmail.com

The North China Craton (NCC) is the largest gold producer in China, contributing to over two thirds of the national gold production. On the northern margin of the NCC the gold deposits are primarily hosted within the Precambrian metamorphic rocks and associated with Jurassic-Triassic intrusions. The most significant example is the Jinchangyu gold deposit, which contains a resource of $90 \mathrm{t}$ gold with averaging $5.3 \mathrm{~g} / \mathrm{t} \mathrm{Au}$. The genesis of the deposit can be attributed to either a Precambrian metamorphic or a Jurassic-Triassic magmatic-hydrothermal origin. New auriferous pyrite Re-Os dating and He-Ar-Sr-Nd isotopic analyses are used to constrain the timeline of gold mineralization and the source of ore-forming materials. The low level highly radiogenic auriferous pyrite samples yield a Re-Os isochron age of $223.5 \pm 6.0 \mathrm{Ma}$ with a weighted mean model age of 224.5 $\pm 3.6 \mathrm{Ma}$ (Fig.1), suggesting that the gold mineralization occurred in the Triassic. The ${ }^{3} \mathrm{He} /{ }^{4} \mathrm{He}$ ratios of the auriferous pyrite range from 1.72 to $3.92 \mathrm{Ra}\left(\mathrm{Ra}=1.39 \times 10^{-6}\right.$ for air), corresponding to $22-50 \%$ mantle ${ }^{4} \mathrm{He}$ contribution. The ${ }^{40} \mathrm{Ar} /{ }^{36} \mathrm{Ar}$ ratios are in the range of 2638.61-5946.59, significantly higher than that of atmospheric value of 295.5. Furthermore, the ${ }^{40} \mathrm{Ar} * /{ }^{4} \mathrm{He}$ ratios range from 0.66 to 3.03 , which are higher than those of the mantle of $0.3-0.5$ and crust of 0.2 . This implies an additional ${ }^{40} \mathrm{Ar}$ source which is likely to be the Neoarchean host rock of plagioclase amphibolite, as previous study suggests amphibole in the host rock can potentially be the source of Ar. The combined He-Ar isotopes suggest that both the Neoarchean host rock and some mantle components related to the Triassic magmatism contributed to the gold mineralization. This is further supported by $\mathrm{Sr}-\mathrm{Nd}$ isotopes of the auriferous pyrite. The pyrite has $\mathrm{Sr}-\mathrm{Nd}$ isotopic compositions largely overlapping with the Neoarchean host rocks and marginally intersecting with the late Triassic granites (Fig.2). To conclude, the isotopic systematics of the auriferous pyrite suggest that the genesis of the Jinchangyu gold deposit is collectively affected by the Neoarchean metamorphic host rock and the Triassic magmatic intrusions.
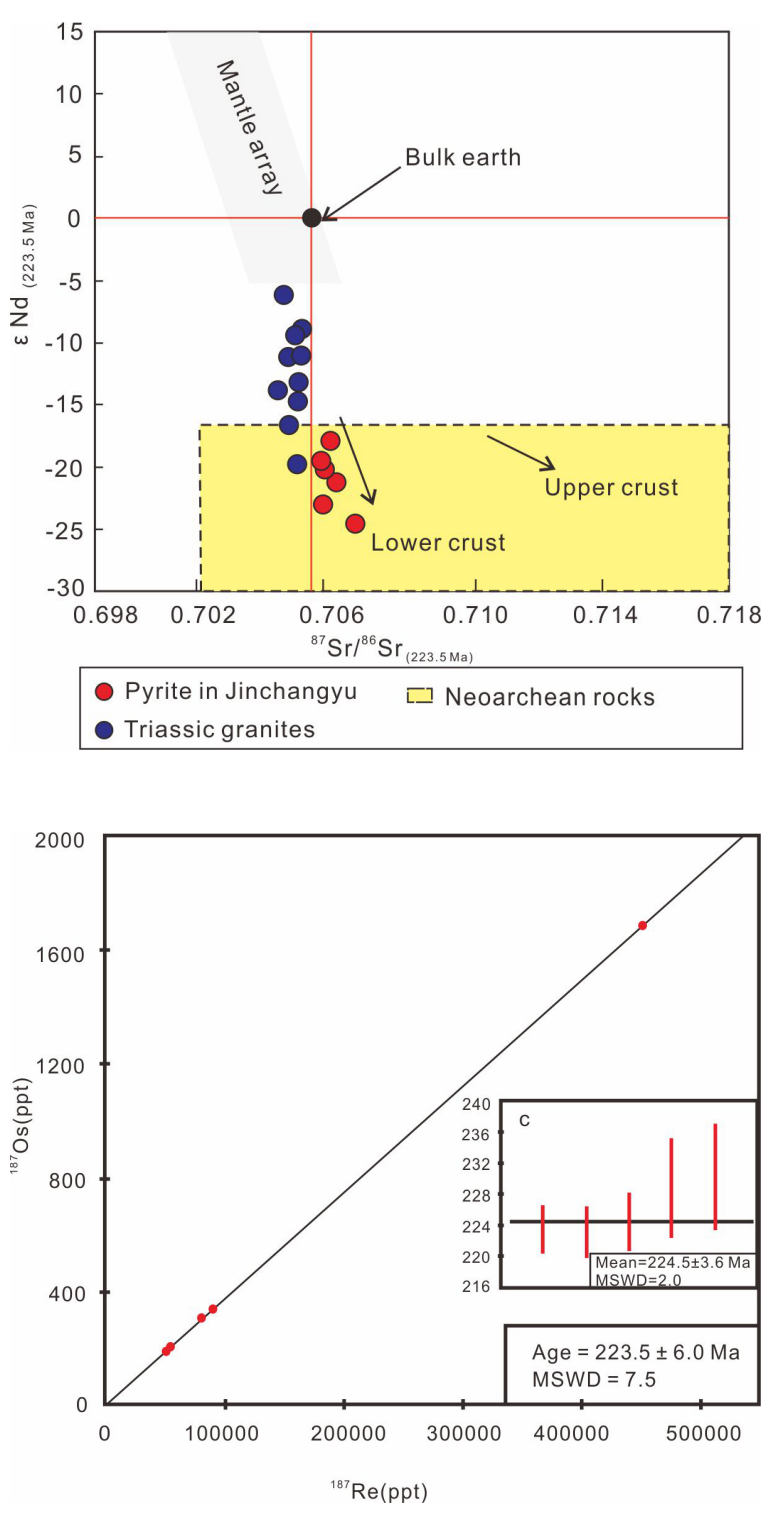